\title{
Anaerobic mineralization in marine sediments from the Baltic Sea-North Sea transition
}

\author{
Bo Barker Jørgensen, Mathilde Bang, T. Henry Blackburn \\ Department of Ecology and Genetics, University of Aarhus, Ny Munkegade, DK-8000 Aarhus C, Denmark
}

\begin{abstract}
Mineralization was studied within the upper $2 \mathrm{~m}$ of sediments from the Belt Sea, Kattegat. and Skagerrak at 15 to $200 \mathrm{~m}$ water depth. Radiotracer measurements of sulfate reduction rates were related to porewater chemistry $\left(\mathrm{SO}_{4}{ }^{2-}, \mathrm{HCO}_{3}{ }^{-}, \mathrm{PO}_{4}{ }^{3-}, \mathrm{NH}_{4}{ }^{+}, \mathrm{H}_{2} \mathrm{~S}\right.$, and $\left.\mathrm{CH}_{4}\right)$, to solid-phase chemistry $(\mathrm{C}, \mathrm{S}, \mathrm{N}$, and $\mathrm{Fe}$ ), and to bacterial distributions. Sulfate penetrated 0.9 to $>3.5 \mathrm{~m}$ into the sediment. Sulfate reduction rates decreased $>100$-fold from maxima of 6 to $74 \mathrm{nmol} \mathrm{cm}^{-3} \mathrm{~d}^{-1}$ at the surface to between 0.1 and $1 \mathrm{nmol} \mathrm{cm} \mathrm{cm}^{-3} \mathrm{~d}^{-1}$ at 1 to $2 \mathrm{~m}$ depth. Between 8 and $88 \%$ of the total, depth-integrated sulfate reduction took place within the uppermost 0 to $15 \mathrm{~cm}$ of the sediment. Maxima of sulfate reduction or bacterial densities at the sulfate-methane transition indicated a zone of anaerobic methane oxidation 0.8 to $>2.5 \mathrm{~m}$ below the surface. The fraction of the iron pool, which was bound in pyrite, was 17 to $42 \%$, even in the presence of $>1 \mathrm{mM} \mathrm{H}_{2} \mathrm{~S}$. Only 4 to $32 \%$ of the $\mathrm{H}_{2} \mathrm{~S}$ produced from sulfate reduction was permanently buried as $\mathrm{FeS}_{2}$ while the rest was reoxidized. Sediment accumulation rates determined from ${ }^{210} \mathrm{~Pb}$ age determinations were 0.3 to $6.2 \mathrm{~mm} \mathrm{yr}^{-1}$. The total deposition of organic carbon, determined from the sum of organic $C$ mineralized by aerobic and anaerobic respiration plus net burial of organic $\mathrm{C}_{\text {, was }} 16.7$ to $52.3 \mathrm{mmol} \mathrm{m} \mathrm{m}^{-2} \mathrm{~d}^{-1}$. This was equivalent to about $50 \%$ of the primary productivity in the water column. The net burial rates of organic C were 1.5 to $26 \mathrm{mmol} \mathrm{m}^{-2} \mathrm{~d}^{-1}$ corresponding to 9 to $50 \%$ of the deposited organic $C$. The burial of pyritic sulfur corresponded to 9 to $37 \%$ of the reducing equivalentes buried as organic C.
\end{abstract}

\section{INTRODUCTION}

Mineralization of organic matter in marine sediments occurs very intensively within the oxic and suboxic surface layers. The mineralization continues via the anaerobic respiration of sulfate-reducing bacteria down through the sulfate zone. This zone varies in depth in shelf sediments from a few decimetres under the highest organic deposition rates to many metres under low deposition rates.

Determinations of the rates of sulfate reduction within the upper sediment layers are generally done by radiotracer techniques (Skyring 1987). Determinations down to several metres have mostly be done indirectly from diffusion-diagenesis models based on the shape of sulfate gradients, on the organic pool size, and on the molecular diffusion coefficient of sulfate (Berner 1980a). In only a few studies have radiotracer measurements been done throughout the sulfate reduction zone down to 1 or several metres (e. g. Jørgensen 1977). It is therefore not well understood what fraction of the total depth-integrated sulfate reduction is detected when measurements are done only within the upper few decimetres of the sediment.

The total, cumulative sulfate reduction as well as its depth distribution depend on the sedimentation rate of organic carbon, its microbial degradability, the rate of sediment burial, the intensity and depth of bioturbation, etc. A rough proportionality between net sedimentation rate and depth-integrated sulfate reduction was found by modeling sulfate gradients for a wide range of sediment types (Toth \& Lerman 1977). The overall mineralization of organic matter, however, gradually shifts from sulfate reduction toward aerobic respiration with decreasing sedimentation rates (e.g. Jørgensen 1982, Canfield 1989a, Christensen 1989). When compared over all depth regions of the ocean, the cumulative sulfate reduction may therefore be more important in determining the total amount of organic carbon preserved than in determining the total amount mineralized (Henrichs \& Reeburgh 1987).

In the present study we have measured rates of sulfate reduction from the surface to 1 to $2 \mathrm{~m}$ depth by radiotracer injections into undisturbed sediment cores. 
The depth distributions of mineralization rates were used to calculate budgets of sulfur cycling and of the efficiency of organic carbon burial relative to carbon reoxidation.

\section{MATERIALS AND METHODS}

Sampling. Sediment cores were obtained from 6 stations in the Belt Sea, Kattegat, and Skagerrak which connect the Baltic Sea and the North Sea (Fig. 1). The stations are numbered according to Jørgensen (1989) and Jørgensen \& Revsbech (1989) where geographical positions and further descriptions of the sediments are given. The sediments were silt and clay with organic contents ranging from 7 to $12 \%$ dry wt. Water depths ranged from 17 to $200 \mathrm{~m}$.

Cores were taken during 2 cruises with RV 'Martin Knudsen' (National Agency of Environmental Protection, Denmark) in November 1978 and July 1979. Cores of 2 to $3 \mathrm{~m}$ length and $7 \mathrm{~cm}$ i.d. were taken with a Kullenberg piston corer. After sampling, the core-liner was immediately separated into $60 \mathrm{~cm}$ sections and $15 \mathrm{~cm}$ long subcores were taken as the sediment was gradually pushed out with a piston. Subcores were stored for 5 to $10 \mathrm{~h}$ at in situ temperature in a thermo-

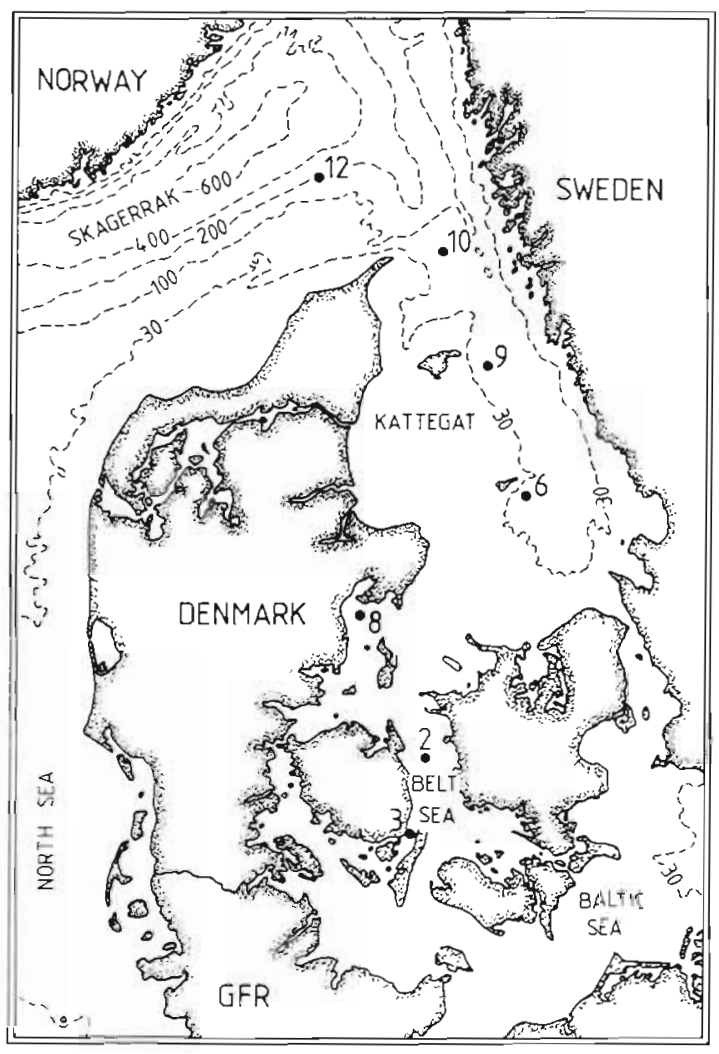

Fig. 1. Positions of sampling sations in the Belt Sea, Kattegat, and Skagerrak stated incubator until further treatment. Subcores of undisturbed surface sediment were obtained from a Haps corer (Kanneworff \& Nicolaisen 1973). Chemical and bacterial depth distributions were aligned for the 2 core sets by comparison of chemical porewater gradients

Sulfate reduction. Rates of bacterial sulfate reduction were measured by ${ }^{35} \mathrm{SO}_{4}{ }^{2-}$ core injection technique in 3 or 4 replicate cores (Jorgensen 1978a). Cores were incubated in the dark at in situ temperature for 6 to $10 \mathrm{~h}$. Incubation was stopped by freezing and reduced ${ }^{35} \mathrm{~S}$ was recovered from the acid-volatile sulfide (AVS) fraction by distillation with $2 \mathrm{~N} \mathrm{HCl}$ under $\mathrm{N}_{2}$ flow. The evolved $\mathrm{H}_{2}{ }^{35} \mathrm{~S}$ was trapped in $10 \mathrm{ml} 2 \%$ $\mathrm{Zn}$-acetate. Subsamples were taken of ${ }^{35} \mathrm{SO}_{4}{ }^{2-}$ and $\mathrm{H}_{2}{ }^{35} \mathrm{~S}$ for radioactivity determination and sulfate reduction rates were calculated.

Bacteria. Total counts of bacteria were done under an epifluorescence microscope after staining with acridine orange (Dale 1974, Hobbie et al. 1977, Rublee \& Dornseif 1978)

Subsamples of sediment were fixed in $2 \%$ formaldehyde made up in $0.2 \mu \mathrm{m}$ membrane filtered seawater and kept refrigerated until counting. The sediment was then diluted with $0.2 \mu \mathrm{m}$ filtered seawater and blended. Sand grains were allowed to settle before staining and filtration of 3 subsamples of the suspension. Ten fields were counted under the microscope at $1000 \times$ for each subsample. The relative standard error of the mean of bacterial density for each depth increased from about $\pm 15 \%$ near the surface to $\pm 30 \%$ deep in the cores.

Porewater analyses. Pore water was obtained from $2 \mathrm{~cm}$ thick core segments by squeezing through $0.45 \mu \mathrm{m}$ membrane filters under $\mathrm{N}_{2}$ (Reeburgh 1967). Pore water for sulfide analysis was collected directly in $2 \% \mathrm{Zn}$-acetate to fix the sulfide as $\mathrm{ZnS}$. The sulfide was determined photometrically by the methylene blue method (Cline 1969). Sulfate was determined gravimetrically after precipitation as $\mathrm{BaSO}_{4}$ (APHA 1971). Chloride was analysed on an automatic chloride titrator (Radiometer CMT 10). Bicarbonate was determined from alkalinity titrations with standardized $0.1 \mathrm{~N}$ $\mathrm{HCl}$. Orthophosphate and ammonia were determined photometrically on an autoanalyzer (Chemlab Instruments, Essex) using the methods of Chan \& Riley (1970) and Solorzano (1969), respectively.

Subsamples for measurement of dissolved $\mathrm{CH}_{4}$ were fixed with $\mathrm{NaOH}$ in stoppered glass vials and shaken. After gas equilibration, subsamples were taken of the headspace and analyzed on a gas chromatograph with a flame ionization detector. Samples from sediments with $>1$ atm $\mathrm{CH}_{4}$ developed bubbles which caused loss of gas.

Sediment analyses. FeS was determined from the AVS distilled for the measurement of sulfate reduction. 
Subsamples of $\mathrm{ZnS}$ were taken from the $\mathrm{H}_{2}{ }^{35} \mathrm{~S}$ traps and sulfide was analyzed by the methylene blue method after appropriate dilution (Cline 1969). The pore water concentrations of $\mathrm{H}_{2} \mathrm{~S}$ were subtracted from the AVS data to calculate FeS concentrations.

Sediment was dried at $106^{\circ} \mathrm{C}$ and ground in a mortar for elemental analyses. Total sulfur was analysed on a LECO induction furnace provided with a titration unit for the evolved $\mathrm{SO}_{2}$. The measured sulfate and AVS concentrations were subtracted. The remaining sulfur was mostly $\left(>90 \%\right.$ ) pyrite, $\mathrm{FeS}_{2}$, plus smaller amounts of elemental sulfur, $\mathrm{S}^{\circ}$ (cf. Sørensen \& Jørgensen 1987 , Thode-Andersen \& Jørgensen 1989) and organic sulfur.

Acid-soluble iron, $\mathrm{Fe}_{\mathrm{HCl}}$, was extracted by boiling fresh sediment samples for $1 \mathrm{~min}$ in $12 \mathrm{~N} \mathrm{HCl}$ (Berner 1970). Dissolved iron was measured by atomic absorption spectrophotometry. The degree of pyritization, $P$, was calculated as a measure of the fraction of the available iron pool which was bound in pyrite. $P$ was calculated from the acid-soluble iron and the iron present in pyrite $\left(\mathrm{Fe}_{\mathrm{py}}=1 / 2 \mathrm{~S}_{\mathrm{py}}\right)$ according to Berner (1970):

$$
P=\mathrm{Fe}_{\mathrm{pY}} /\left(\mathrm{Fe}_{\mathrm{py}}+\mathrm{Fe}_{\mathrm{HCl}}\right)
$$

Total carbon and nitrogen were determined on a CHN analyzer (Carlo-Erba). Combustion temperature was $700{ }^{\circ} \mathrm{C}$. Samples were not acidified first to remove carbonates. Controls showed that acidification caused small losses of both $\mathrm{C}$ and $\mathrm{N}$ in similar proportion as the sediment $\mathrm{C}: \mathrm{N}$ composition. This was interpreted as leaching of organic matter rather than loss of carbonates.

Sedimentation. Rates of sediment accumulation were calculated from the depth decay of the particleassociated radionuclide, ${ }^{210} \mathrm{~Pb}$, which has a half-life of 22 yr (e.g. Madsen \& Sorensen 1979). Sedimentation rates were expressed both as $\mathrm{mg}$ dry $\mathrm{wt} \mathrm{cm}^{-2} \mathrm{yr}^{-1}$ and as the average accumulation in $\mathrm{mm}_{\mathrm{yr}}{ }^{-1}$ for sediment at 10 to $20 \mathrm{~cm}$ depth just below the mixed zone. Sediment mixing depths caused by bioturbating fauna and possibly by sediment resuspension and transport were also determined from the ${ }^{210} \mathrm{~Pb}$ distributions.

\section{RESULTS}

Seven sets of piston cores were obtained during 2 cruises from a wide range of sediment types typical for the Baltic Sea-North Sea transition. Only hard sandy sediments were not included as they could not be cored below a few decimetres depth. The stations included protected coastal areas of $<20 \mathrm{~m}$ depth (Stns 3 and 8 ), the Belt Sea (Stn 2), the central (Stn 6) and northern Kattegat (Stn 10), and the deeper Skagerrak at $200 \mathrm{~m}$ water depth (Stn 12). Only Stn 2 was sampled during both cruises. Stns 6 and 12 are identical to Stns A and C, respectively, of Iversen \& Jørgensen (1985), who studied sulfate reduction with special emphasis on the sulfate-methane interface. Reference is made in the following also to Stn 9 of Jorgensen (1989), which is identical to Stn B of Iversen \& Jørgensen (1985).

The water column of the area is highly stratified in salinity with 30 to $34 \%$ North Sea water below the pycnocline situated at 10 to $20 \mathrm{~m}$ depth and Baltic brackish water of 20 to $30 \%$ above. Temperatures at the surface and bottom were 7 to $10^{\circ} \mathrm{C}$ in November, while in July temperatures were around $15^{\circ} \mathrm{C}$ at the surface and 5 to $8^{\circ} \mathrm{C}$ at the bottom.

\section{Station 2}

About $70 \%$ of the net water flow out of the Baltic Sea passes through the Great Belt. Stn 2, which was positioned in a flat mud basin in the middle of the Belt, had a relatively low sedimentation rate (Table 1). Net sedimentation in this area following the last glaciation may now have almost stopped (Winn 1974). Sulfate penetrated below the coring depth of $2.5 \mathrm{~m}$ and reached an extrapolated depth of 3 to $3.5 \mathrm{~m}$ (Fig. 2). Methane began accumulating at $1.6 \mathrm{~m}$ depth where the sulfate concentration had fallen to $8 \mathrm{mM}$.

Sulfate reduction rates are plotted logarithmically together with the bacterial distribution in Fig. 2 as well as in the following 3 figures. The logarithmic presentation was chosen in order to present both the high rates of activity near the surface and the low rates in the deeper layers. The log plot, however, tends to emphasize the higher variability and noise of the lower rates. It should therefore be noticed that most of the overall sulfate reduction in the sediment took place within the uppermost few decimetres where sampling density and accuracy in rate determination were high.

Maximal activity of sulfate reduction was reached at $5 \mathrm{~cm}$ depth. Above $5 \mathrm{~cm}$ the rates decreased steeply towards the oxidized surface layer. Below $5 \mathrm{~cm}$ the rates also decreased steeply into deeper layers with older and less degradable organic matter. At 1 to $2 \mathrm{~m}$ depth sulfate reduction still continued at rates of 0.1 to $0.2 \mathrm{nmol} \mathrm{cm}{ }^{-3} \mathrm{~d}^{-1}$ which was about $0.5 \%$ of the maximal activity. In the $\mathrm{SO}_{4}{ }^{2-}-\mathrm{CH}_{4}$ transition zone at 2 to $2.5 \mathrm{~m}$ sulfate reduction tended to increase again, presumably because the bacteria were here, directly or indirectly, utilizing methane as an energy source (Iversen \& Jørgensen 1985). The bacterial distribution showed a 100 -fold decrease in population density between the highest numbers at the sediment surface, $2.6 \times 10^{8}$ bacteria $\mathrm{cm}^{-3}$, and the minimum just above the methane zone. The physiological types of bacteria must change according to the vertical zones of aerobic respiration, denitrification, sulfate reduction, etc. This is not reflected in the vertical distribution which rather 
shows how the degradability of sediment organic matter changed with depth. Bacterial density also increased in the $\mathrm{SO}_{4}{ }^{2-}-\mathrm{CH}_{4}$ transition zone.

$\mathrm{H}_{2} \mathrm{~S}$ in the porewater was undetectable in the upper 0 to $6 \mathrm{~cm}$ layer and accumulated almost linearly below that depth. The brown, oxidized layer comprised the upper 0 to $3 \mathrm{~cm}$. The black iron monosulfide zone was sharply defined between 3 and $20 \mathrm{~cm}$ depth below which the sediment was grey.

The inorganic nutrient distribution in the pore water showed the progressive mineralization with depth. Dissolved inorganic carbon, produced from the respiration of sediment organic matter, increased linearly throughout the sulfate zone. Nitrate was only present in the uppermost 1.5 to $5 \mathrm{~cm}$ (Blackburn \& Henriksen 1983). Free ammonia increased linearly with depth to several mM concentration. An additional pool of ammonia, which could be exchanged and extracted with potassium ions, occurred adsorbed to the sediment. This pool was highest near the surface $\left(0.35 \mu \mathrm{mol} \mathrm{cm}^{-3}\right)$ and constituted a minor fraction of the ammonia in the deeper layers (Blackburn \& Henriksen 1983). Phosphate built up steeply below the oxidized surface sediment. In contrast to ammonia and inorganic carbon it approached a constant level in the deeper layers.

\section{Station 8}

This station was positioned in the central part of the mud basin in Aarhus Bay at $17 \mathrm{~m}$ water depth. The sediment accumulation rate was relatively low as this basin too may gradually have filled in to a depth of balancing sedimentation and resuspension (Larsen \& Madsen 1986). This was the only station at which there was a significant decrease in chloride concentration of the pore water, from $460 \mathrm{mM}$ at the surface to $30 \mathrm{mM}$ at $2 \mathrm{~m}$ depth (Fig. 3). Chloride is therefore not shown for the other stations.

Sulfate penetrated to $2 \mathrm{~m}$ depth below which the sediment was rich in methane. Sulfate reduction showed a distinct maximum at $5 \mathrm{~cm}$ depth and a secondary maximum at the $\mathrm{SO}_{4}{ }^{2-}-\mathrm{CH}_{4}$ transition zone. Such a secondary maximum was not detectable in the bacterial distribution. The $\mathrm{H}_{2} \mathrm{~S}$ concentration approached a maximum value towards the lower boundary of the sulfate zone. The black FeS zone was narrow and very distinct, while the inorganic ions showed rather similar distributions as at Stn 2

\section{Stations 10 and 12}

Stn 10 was situated in the northern Kattegat on the western mud slope of the Deep Trough at $73 \mathrm{~m}$ depth. The sediment accumulation rate was extremely high, $6.2{\mathrm{~mm} \mathrm{yr}^{-1}}^{-1}$, which is in accordance with the known, rapid formation of fine-grained deposits in this area (Fält 1982). Sulfate penetrated to $160 \mathrm{~cm}$ depth (Fig. 4). Methane diffused up to between 70 and $80 \mathrm{~cm}$ depth and the $\mathrm{SO}_{4}{ }^{2-}-\mathrm{CH}_{4}$ transition thus comprised half of the whole sulfate zone. Below $115 \mathrm{~cm}$ depth the methane exceeded 1 atm partial pressure at ambient temperature and gas bubbles developed in the sediment cores after they were retrieved on deck. Since no precautions were taken to maintain in situ pressure, much of the methane gas from layers below $115 \mathrm{~cm}$ was lost and concentrations from here are therefore underestimated.

A smiliar situation was observed at Stn 12 in Skagerrak on the southern slope of the Deep Trough at $200 \mathrm{~m}$ depth (Fig. 5). Sediment accumulation was also high,

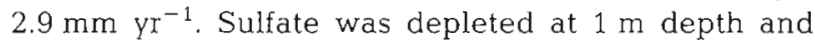
there was only a narrow $\mathrm{SO}_{4}{ }^{2-}-\mathrm{CH}_{4}$ transition zone. Methane gas bubbles developed below $105 \mathrm{~cm}$ depth. The shape of the sulfate gradient above $80 \mathrm{~cm}$ depth, which showed increasing slope with depth, could indicate compression during coring. The gradient was, however, identical to the sulfate gradient measured at this station 2 yr later with a different piston corer

Table 1 Seven sediment stations in the Belt Sea, the Kattegat, and the Skagerrak: water depths, sediment accumulation rates below the mixing zone in $\mathrm{mm} \mathrm{yr}^{-1}$ and mg dry wt $\mathrm{cm}^{-2} \mathrm{yr}^{-1}$, depths of sulfate penetration into the sediment, sulfate reduction rates (SRR) per unit area integrated throughout the sulfate zone, and sulfate reduction rates at depths of maximal activity per unit volume of sediment

\begin{tabular}{|c|c|c|c|c|c|c|}
\hline Stn & $\begin{array}{l}\text { Depth } \\
(\mathrm{m})\end{array}$ & $\begin{array}{l}\text { Sedimer } \\
\left(\mathrm{mm} \mathrm{yr}^{-1}\right)\end{array}$ & $\begin{array}{l}\text { ccum, rate } \\
\left(\mathrm{mg} \mathrm{cm}^{-2} \mathrm{yr}^{-1}\right)\end{array}$ & $\begin{array}{c}\mathrm{SO}_{4}^{2-} \text { zone depth } \\
(\mathrm{m})\end{array}$ & $\begin{array}{c}\text { SRR areal } \\
\left(\mathrm{mmol} \mathrm{m} \mathrm{m}^{-2} \mathrm{~d}^{-1}\right)\end{array}$ & $\begin{array}{c}\text { SSR maximal } \\
\left(\mathrm{nmol} \mathrm{cm}^{-3} \mathrm{~d}^{-1}\right)\end{array}$ \\
\hline 2 & 25 & 0.3 & 17 & $3-3.5$ & 4.67 & 36 \\
\hline 3 & 15 & 5.3 & 340 & 0.9 & 5.78 & 74 \\
\hline 6 & 43 & 0.5 & 33 & $>3.5$ & 3.39 & 6 \\
\hline 8 & 17 & 0.5 & 30 & 2.0 & 2.38 & 23 \\
\hline 9 & 65 & 1.6 & 70 & 1.6 & 7.91 & 15 \\
\hline 10 & 73 & 6.2 & 430 & 1.6 & 5.61 & 39 \\
\hline 12 & 200 & 2.9 & 230 & 1.0 & 5.13 & 28 \\
\hline
\end{tabular}


Fig. 2. Stn 2 in the Great Belt: depth distribution of porewater chemistry, iron sulfide, sulfate reduction rates (SRR), and total bacterial numbers
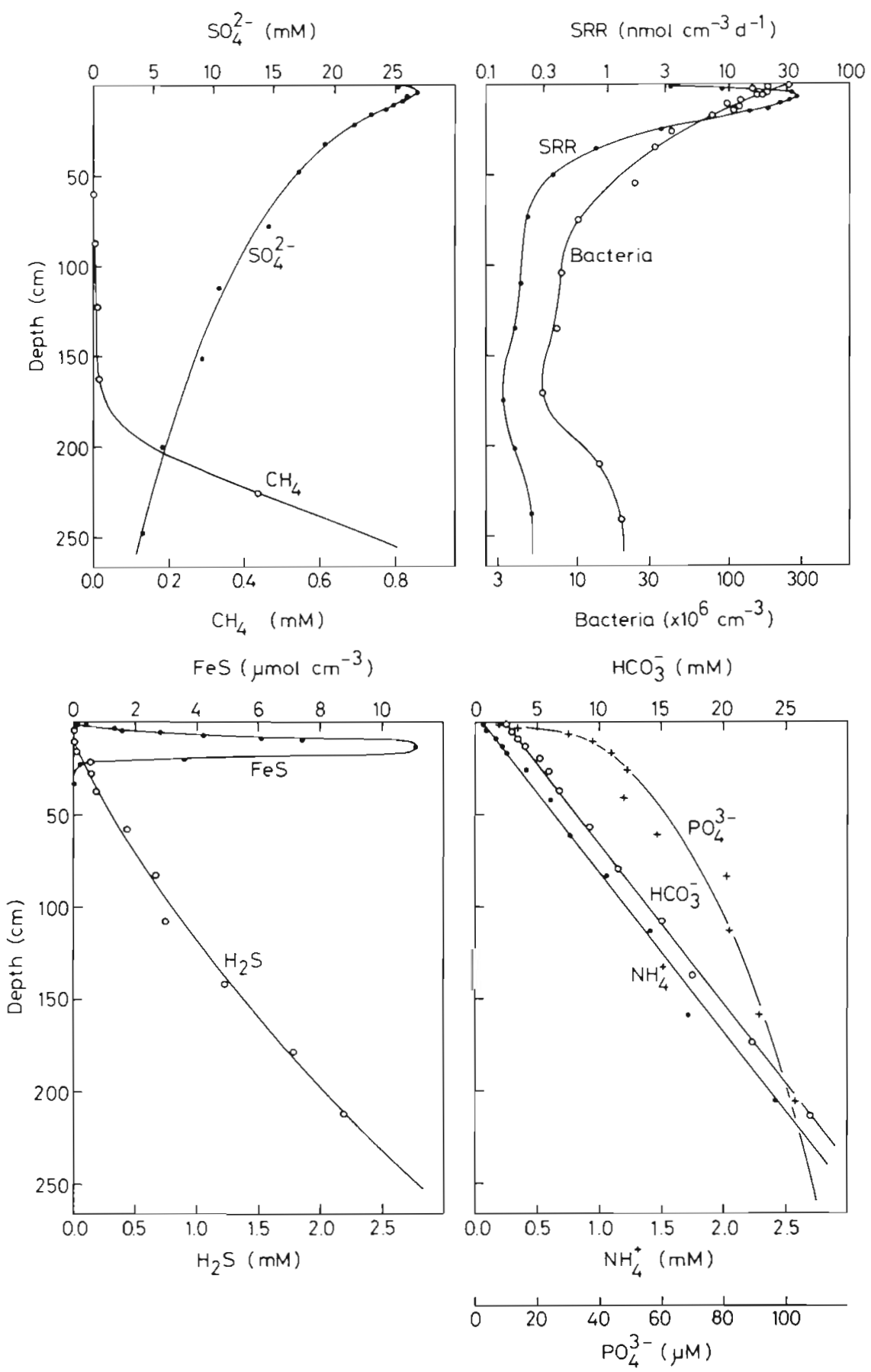

(Iversen \& Jørgensen 1985). The maximum rates of sulfate reduction at Stns 10 and 12 were not higher than at Stns 2 and 8 , but the zone of high reduction was deeper and the integrated reduction rates were therefore higher (Table 1).

Free $\mathrm{H}_{2} \mathrm{~S}$ was not detectable in the upper few decimetres of Stns 10 and 12 (Figs. 4 and 5). It reached a maximum at the lower boundary of the sulfate zone below which it decreased again. This decrease may be enhanced by loss of $\mathrm{H}_{2} \mathrm{~S}$ gas together with $\mathrm{CH}_{4}$ due to bubble formation. A smiliar decrease below the sulfate zone has, however, also been observed in sediments without methane gas bubbles (e.g. Jørgensen 1977). There was not a distinct, black iron monosulfide zone in these rapidly accumulating sediments. Although a FeS maximum was found around $20 \mathrm{~cm}$ depth, the FeS was high throughout the cores and even increased below the sulfate zone at Stn 12 . 

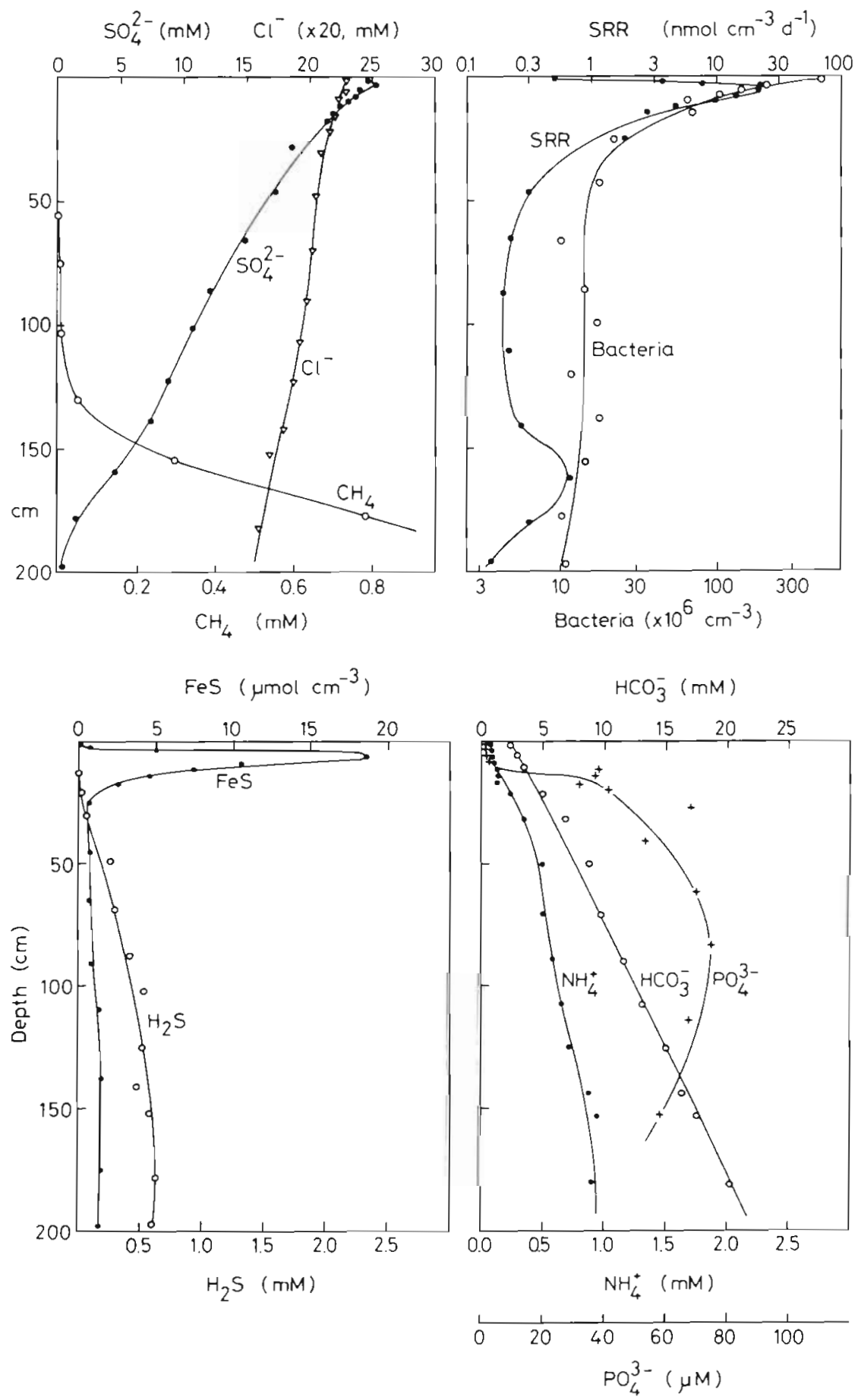

Fig. 3. Stn 8 in Aarhus Bay: for legend see Fig. 2

\section{Stations 3 and 6}

Two additional stations were studied. Stn 3 was situated in a mud basin of Langeland Belt at $15 \mathrm{~m}$ depth where the present sediment accumulation rate was also very high, $5.3 \mathrm{~mm} \mathrm{yr}^{-1}$ (Table 1). The mud deposit was, however, only $70 \mathrm{~cm}$ deep and covered a hard sand horizon into which the piston corer could penetrate only a few decimetres. By extrapolation of the sulfate reduction profile it was estimated that $<5 \%$ of the overall sulfate reduction took place within the sand layer This station had the highest sulfate reduction rates recorded, $74 \mathrm{nmol} \mathrm{cm}^{-3} \mathrm{~d}^{-1}$, with a maximum at 3 to $4 \mathrm{~cm}$ below the sediment surface.

Stn 6 in the central, eastern Kattegat was situated down the slope of the Deep Trough at $43 \mathrm{~m}$ water depth. 

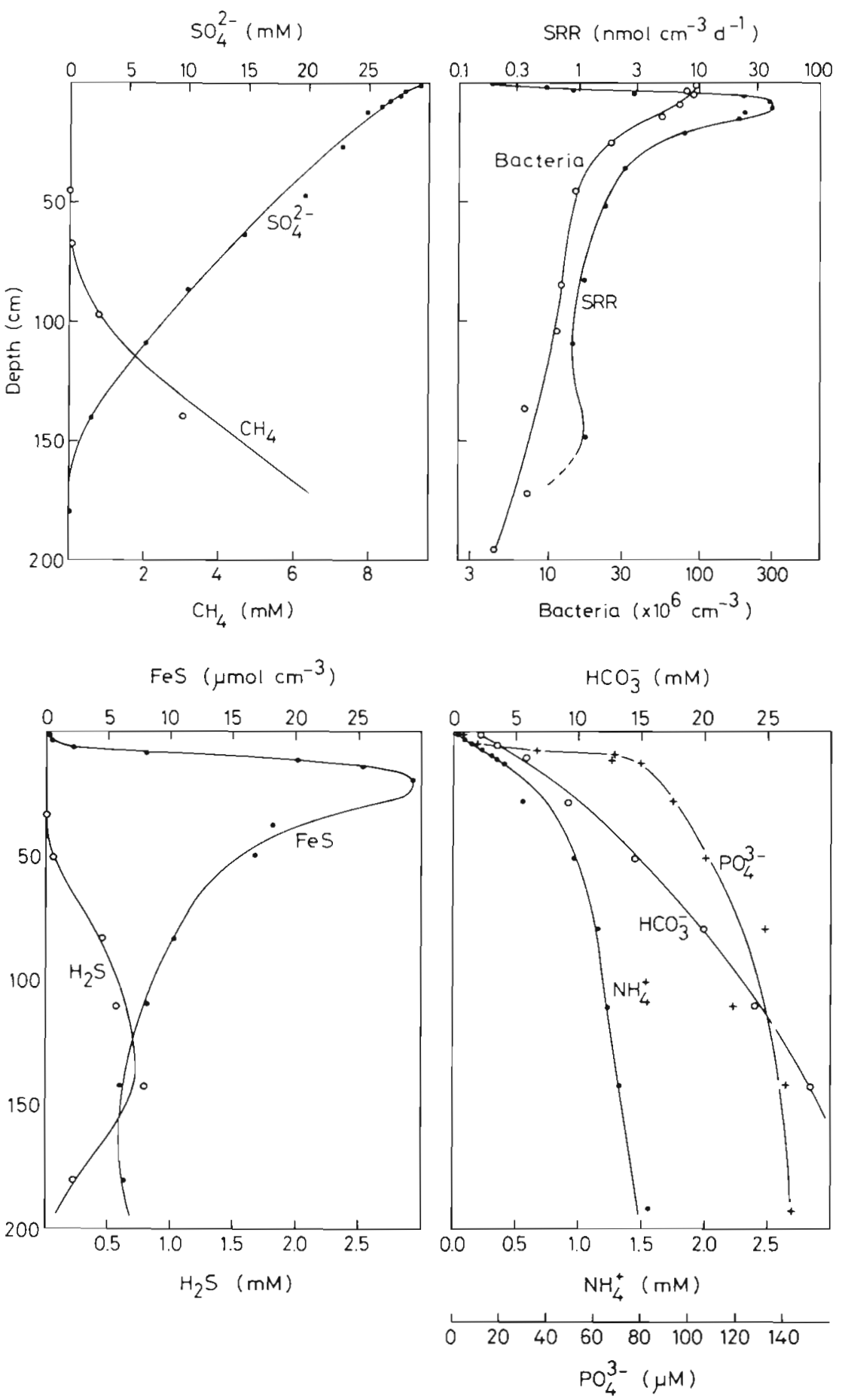

Both sediment accumulation and sulfate reduction rates were relatively low and the sulfate concentration decreased only by 10 to $15 \%$ between the sediment surface and $2 \mathrm{~m}$ depth.

\section{Integrated sulfate reduction}

Although the 4 sediment stations of Fig. 2 to 5 showed only small differences in the maximal sulfate reduction rates, 23 to $39 \mathrm{nmol} \mathrm{cm}^{-3} \mathrm{~d}^{-1}$, there were large differences in the vertical distribution of rates. Since published radiotracer measurements of sulfate reduction have mostly been done only in the uppermost 1 to $2 \mathrm{dm}$ of the sulfate zone, it is important to know how large a fraction of the overall, depth-integrated sulfate reduction is included in that layer. The fraction can be read from our measured sulfate reduction profiles by plotting reduction rates per unit sedi- 

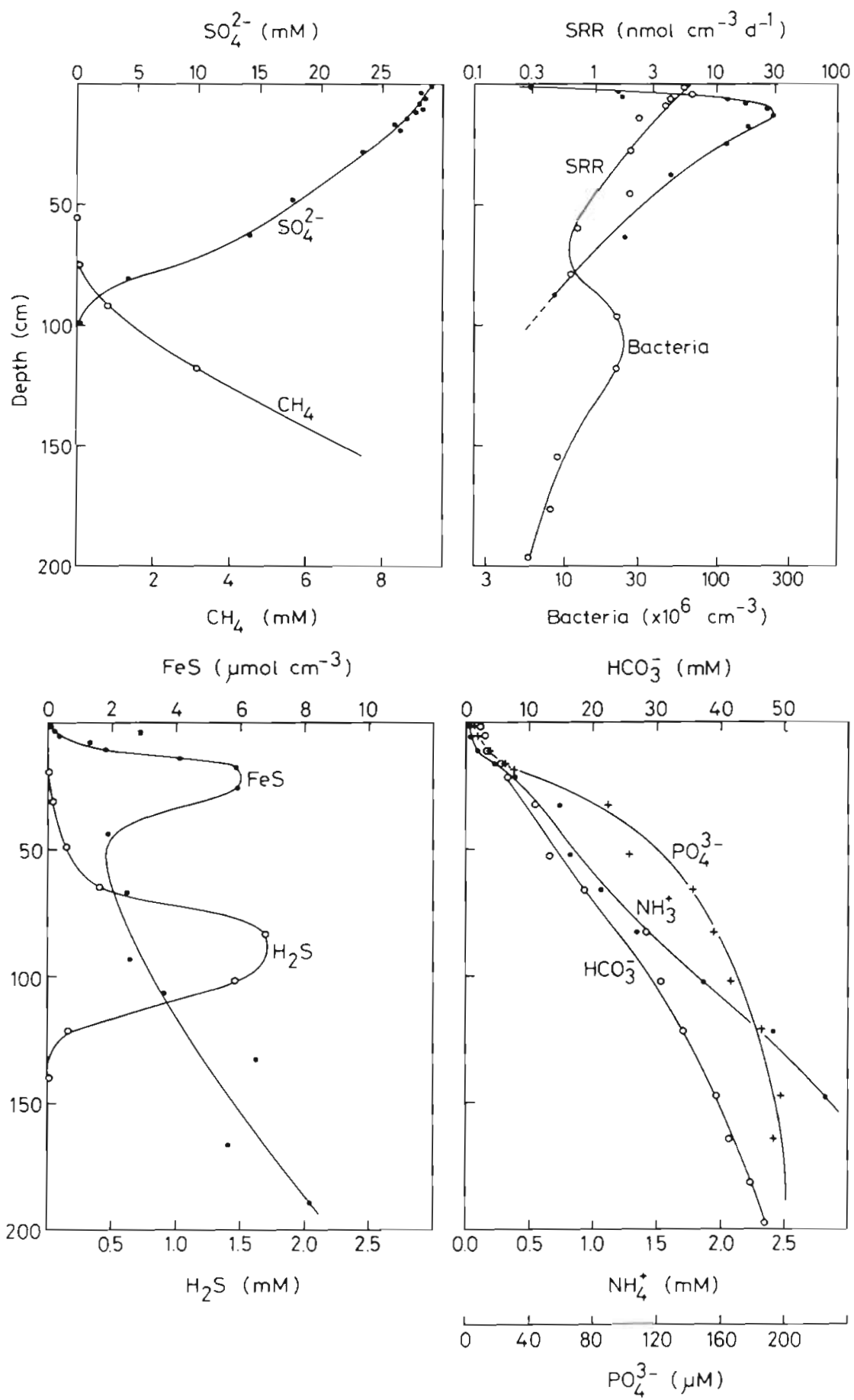

Fig. 5. Stn 12 in southern Skagerrak: for legend see Fig. 2

ment area, integrated from the surface to a given depth, versus depth.

Such a plot is shown in Fig. 6 for the 4 stations of Figs. 2 to 5. Data for Stns 3 and 9 are included for comparison. The depth is shown on a logarithmic scale in order to give a good presentation of both the high activities near the surface and the low activities deeper in the sulfate zone. The integrated rates were calculated in percent of the total rates per unit area given in
Table 1. For Stns 2 and 3, where the lowest part of the sulfate zone was not sampled, the integrated rates for the depths included were taken to be $100 \%$ The $15 \mathrm{~cm}$ depth is particularly marked in Fig. 6 as this is the lower depth of many of our earlier sulfate reduction measurements (e.g. Jørgensen 1982, Jørgensen 1989).

There was a large difference in the depth-integrated rates for the 6 stations plotted in Fig. 6. At Stns 2, 3, and 8 of the Belt Sea, sulfate reduction was more concentrated 
towards the surface layers relative to Stns 9,10, and 12 of northern Kattegat and Skagerrak. The latter were the deeper stations in which bioturbation seemed to affect the bacterial activity and chemical zonation deeper into the sediment. One indication of this difference was found from the ${ }^{210} \mathrm{~Pb}$ data which showed that sediment mixing depths ranged from 5 to $8 \mathrm{~cm}$ at Stn 8 to 15 and $20 \mathrm{~cm}$ at Stns 10 and 12, respectively (Table 2). The deepest mixing zone of $23 \mathrm{~cm}$ was found at $\operatorname{Stn} 9$ which also had the relatively deepest zone of high sulfate reduction. Thus, the deeper the mixing zone due to bioturbation, the more was the sulfate reduction shifted towards deeper layers (Fig. 6). The bioturbation kept the upper sediment layers more oxidized and prevented the accumulation of $\mathrm{H}_{2} \mathrm{~S}$ or FeS. At Stn 9, FeS was very low, $<0.2 \mu \mathrm{mol} \mathrm{cm}{ }^{-3}$, within the upper 0 to $15 \mathrm{~cm}$.

Fig. 6 and Table 2 show that, if measurements of sulfate reduction were restricted to the upper 0 to $15 \mathrm{~cm}$, the fraction of the overall reduction included in the measured rates would vary from $8 \%$ (Stn 9) to $88 \%$ (Stn 3). For a $0-10 \mathrm{~cm}$ depth interval the fraction would be 1.5 to $67 \%$. The latter is similar to the $0-10 \mathrm{~cm}$ fraction, $65 \%$, found for high-organic sediments in the Danish Limfjorden (Jørgensen 1977).

\section{Suliide trapped in pyrite}

A varying fraction of the $\mathrm{H}_{2} \mathrm{~S}$ produced from sulfate reduction reacts with mixed iron oxyhydroxides in the sediment and forms pyrite, $\mathrm{FeS}_{2}$. The FeS, which was found in high concentration in the upper sulfate zone, is not a stable mineral but is gradually recrystallized into pyrite, probably by reaction with elemental sulfur or polysulfides (Berner 1970, Rickard 1975). From simple mass balance calculations it is found that the $\mathrm{H}_{2} \mathrm{~S}$, which is not bound by iron, is lost from the sulfate reduction zone. Free $\mathrm{H}_{2} \mathrm{~S}$ is not detectable in the oxidized zone and consequently it does not diffuse across the sedimentwater interface at significant rates. The $\mathrm{H}_{2} \mathrm{~S}$ must therefore be oxidized within the sediment, most probably to sulfate, which is the dominant dissolved species.

In order to analyze which factors limit the accumulation of sulfur in the sediments studied, the distribution of total sulfur, and in particular of the pyrite fraction, was studied together with the distribution of acidextractable iron, $\mathrm{Fe}_{\mathrm{HCl}}$. This iron fraction does not include that bound in pyrite, which is mostly resistant to hot $\mathrm{HCl}$. The fraction of the iron pool which was bound in pyrite, i.e. the degree of pyritization, $P$, was calculated from the 2 pools, $\mathrm{Fe}_{\mathrm{HCl}}$ and $\mathrm{Fe}_{\mathrm{py}}$.

Fig. 7 shows the distribution of total sulfur, acidsoluble iron, and the degree of pyritization for 4 stations. The higher variability of the data for solid-phase species than for dissolved species reflects variation in the deposited sediment over time. Strong variations are particularly evident over the last 100 yr $(0$ to $50 \mathrm{~cm})$ for Stn 2. Pyrite formation started already in the uppermost 0 to $1 \mathrm{~cm}$ of the sediment at all stations and pyrite accumulated down through the underlying 50 to $100 \mathrm{~cm}$. The $\mathrm{S}_{\text {tot }}$ content of the sediments was highest
Fig. 6. Depth-integrated sulfate reduction rates at 6 stations. Each curve shows the percentage of the total reduction in the sulfate zone which takes place between the surface and a given depth in the sediment. Between 8 and $88 \%$ of the total sulfate reduction took place within the upper 0 to $15 \mathrm{~cm}$ layer

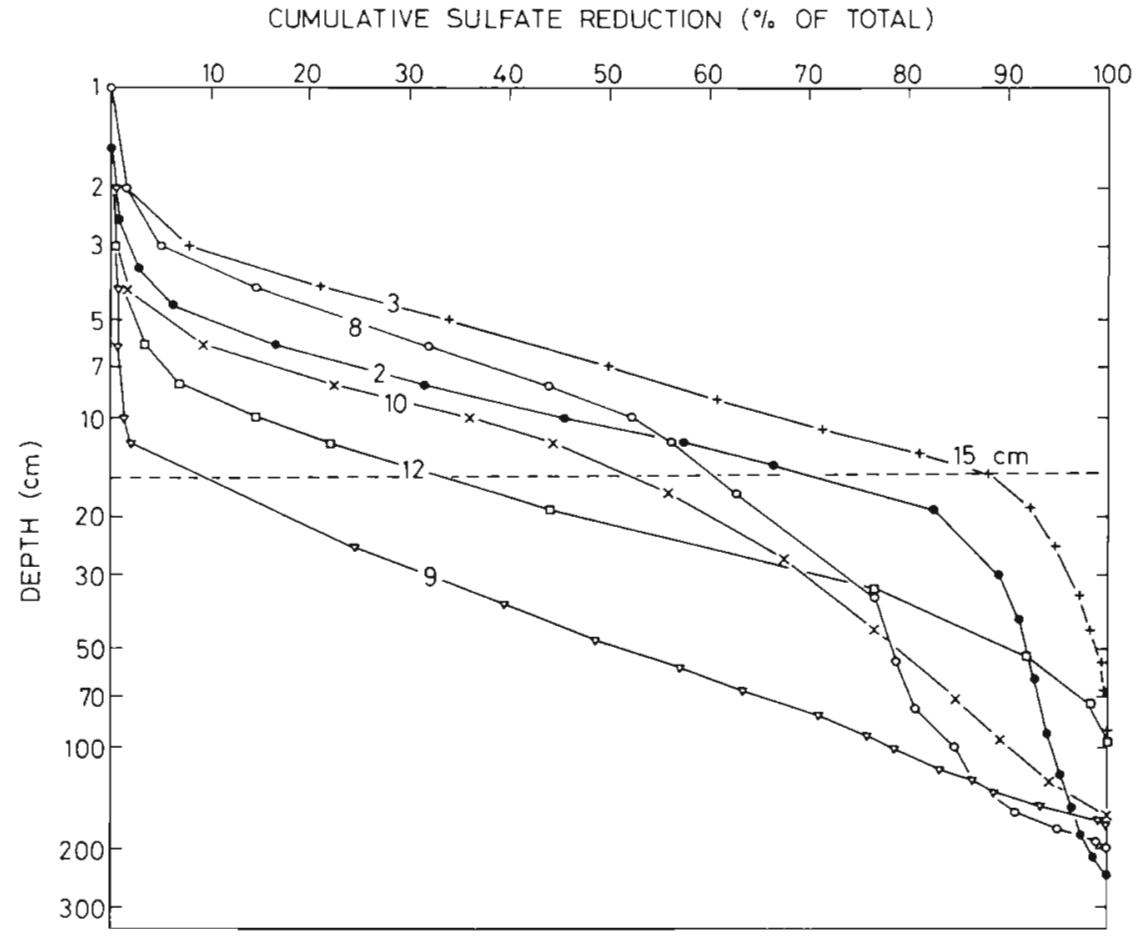


at $\mathrm{Stn} 8$ and lowest at $\mathrm{Stn} 12$. The $\mathrm{Fe}_{\mathrm{HCl}}$ was highest at Stns 8 and 12. The degree of pyritization was therefore high at $\operatorname{Stn} 8$ and low at Stn 12. The average values for the deeper part of the sulfate zone of the 2 stations were $42 \%$ and $17 \%$, respectively (Table 2 ). It is thus only a smaller part of the iron which becomes bound in pyrite at any depth, even in the presence of $>1 \mathrm{mM}$ $\mathrm{H}_{2} \mathrm{~S}$. There was no obvious relation between the degree of pyritization and the rates of $\mathrm{H}_{2} \mathrm{~S}$ production or the $\mathrm{H}_{2} \mathrm{~S}$ concentration (cf. Figs. 2 to 5).

In order to calculate the fraction of $\mathrm{H}_{2} \mathrm{~S}$ produced from sulfate reduction which became trapped as pyrite, the rates of pyrite accumulation were calculated for 2 depth intervals, 0 to $15 \mathrm{~cm}$ and $15 \mathrm{~cm}$ to 'infinity', i.e. to the lower boundary of the sulfate zone (Table 2). The calculation for the upper interval assumed that the initial concentration at the sediment surface was zero. The accumulation was calculated as the product of the increase in pyrite concentration in $\mu \mathrm{mol} \mathrm{cm}^{-3}$ over the depth interval times the sediment accumulation rate in $\mathrm{cm} \mathrm{yr}^{-1}$. The accumulation of pyrite is presented as percent of the sulfate reduction rates in Table 2 . The fraction of the produced $\mathrm{H}_{2} \mathrm{~S}$ which was trapped in pyrite was 2.8 to $40 \%$ for the 0 to $15 \mathrm{~cm}$ depth and 3.2 to $45 \%$ for the 15 to $\infty$ depth. The highest trapping efficiency was found in the most rapidly depositing sediments at Stns 9 and 10. At Stn 9, where most sulfate reduction took place below $15 \mathrm{~cm}$ depth, the highest trapping efficiency was found in the upper $15 \mathrm{~cm}$, and vice versa for $\operatorname{Stn} 10$.

\section{Sulfur cycle budgets}

These calculations are summarized in Fig. 8 for Stns 2 and 10, which represent the lowest and highest $\mathrm{H}_{2} \mathrm{~S}$ trapping efficiencies of all stations. The overall sulfate reduction rates were rather similar. Stn 2 had a relatively low sedimentation rate and most of the sulfate reduction activity took place in the upper 0 to
$15 \mathrm{~cm}$. There was an almost closed sulfur cycle in which $96 \%$ of the $\mathrm{H}_{2} \mathrm{~S}$ was reoxidized to sulfate. Stn 10 had a very high sedimentation rate and half of the sulfate reduction activity took place below $15 \mathrm{~cm}$ depth. There was a less closed sulfur cycle in which only $68 \%$ of the $\mathrm{H}_{2} \mathrm{~S}$ was reoxidized to sulfate.

\section{Burial of carbon, nitrogen, and sulfur}

The differential mineralization of carbon and nitrogen, the trapping of $\mathrm{H}_{2} \mathrm{~S}$ in $\mathrm{FeS}_{2}$, and the rate of sediment accumulation determine the burial of the 3 elements into deeper sediment layers. Two examples of the vertical distribution of the total carbon, nitrogen, and sulfur content are shown in Fig. 9.

Stn 2 had a variable sediment composition over depth, probably due to temporal variations in sedimentation. There were no clear depth trends for carbon or nitrogen, whereas sulfur showed a strong increase in the upper $0.5 \mathrm{~m}$. Stn 10 had a much more constant and high sedimentation rate. Carbon and nitrogen showed gradual decreases over the upper 0.2 to $1 \mathrm{~m}$ while sulfur gradually increased.

Most of the depth variability in the sediment of Stn 2 was removed when the ratios of carbon to nitrogen or carbon to sulfur were calculated (Fig. 9). The C:N ratio increased 2-fold over the upper $0.5 \mathrm{~m}$. The surface value of 10 was higher than the average composition of plankton which has a C:N ratio of 6 to 7 (e.g. Redfield 1958, Redfield et al. 1963). This indicates a preferential mineralization of nitrogen over carbon in the water column before the organic matter was buried into the sediment. At Stn 10 the surface C: $N$ ratio was 15 , which indicates an even more extensive mineralization. This is in accordance with the origin of the sediment in the northern Kattegat. The large mud deposits originate from the North Sea where wave action is too strong for deposition of fine-grained material. It has therefore been transported for long periods and probably under-

Table 2. Sulfate reduction and pyrite formation at 6 sediment stations: mixing depths were estimated from ${ }^{210} \mathrm{pb}$ distributions. Degree of pyritization is the mean value of the lower sulfate zone. Depth-integrated rates of sulfate reduction and pyrite accumulation are calculated for thc depth intervals 0 to $15 \mathrm{~cm}$ and 15 to $x \mathrm{~cm}$, where $x$ is the lower boundary of the sulfate zone.

The percentage of $\mathrm{H}_{2} \mathrm{~S}$ produced which was trapped as $\mathrm{FeS}_{2}$ is calculated for the same depth intervals

\begin{tabular}{|c|c|c|c|c|c|c|c|c|c|}
\hline \multirow[t]{2}{*}{ Stn } & \multirow{2}{*}{$\begin{array}{l}\text { Mixing } \\
\text { depth } \\
(\mathrm{cm})\end{array}$} & \multirow{2}{*}{$\begin{array}{c}\text { Pyritization } \\
P \\
(\%)\end{array}$} & \multicolumn{2}{|c|}{$\begin{array}{c}\mathrm{SRR} \\
\left(\mathrm{mmol} \mathrm{m} \mathrm{m}^{-2} \mathrm{~d}^{-1}\right)\end{array}$} & \multirow{2}{*}{$\begin{array}{c}\text { SRR } \\
0-15: 0-x \\
(\%)\end{array}$} & \multicolumn{2}{|c|}{$\begin{array}{c}\mathrm{FeS}_{2} \text { accum. } \\
\left(\mathrm{mmol} \mathrm{m}^{-2} \mathrm{~d}^{-1}\right)\end{array}$} & \multicolumn{2}{|c|}{$\begin{array}{c}\mathrm{FeS}_{2}: \mathrm{SSR} \\
\%\end{array}$} \\
\hline & & & $0-15$ & $15-x$ & & $0-15$ & $15-x$ & $0-15$ & $15-x$ \\
\hline 2 & - & 30 & 3.27 & 1.40 & 70 & 0.090 & 0.097 & 2.8 & 6.9 \\
\hline 6 & 17 & 28 & 1.90 & 1.49 & 56 & 0.104 & 0.048 & 5.4 & 3.2 \\
\hline 8 & $5-8$ & 42 & 1.43 & 0.95 & 60 & 0.27 & 0.159 & 19.1 & 16.7 \\
\hline 9 & 23 & n.d. & 0.62 & 7.29 & 8 & 0.25 & 0.52 & 39.5 & 7.1 \\
\hline 10 & 15 & 19 & 2.86 & 2.75 & 51 & 0.53 & 1.24 & 18.4 & 45.1 \\
\hline 12 & 20 & 17 & 1.64 & 3.49 & 32 & 0.23 & 0.43 & 14.0 & 12.3 \\
\hline
\end{tabular}


Fig. 7. Distribution of acid-extractable iron, total sulfur, and degree of pyritization, $P$, at 4 stations
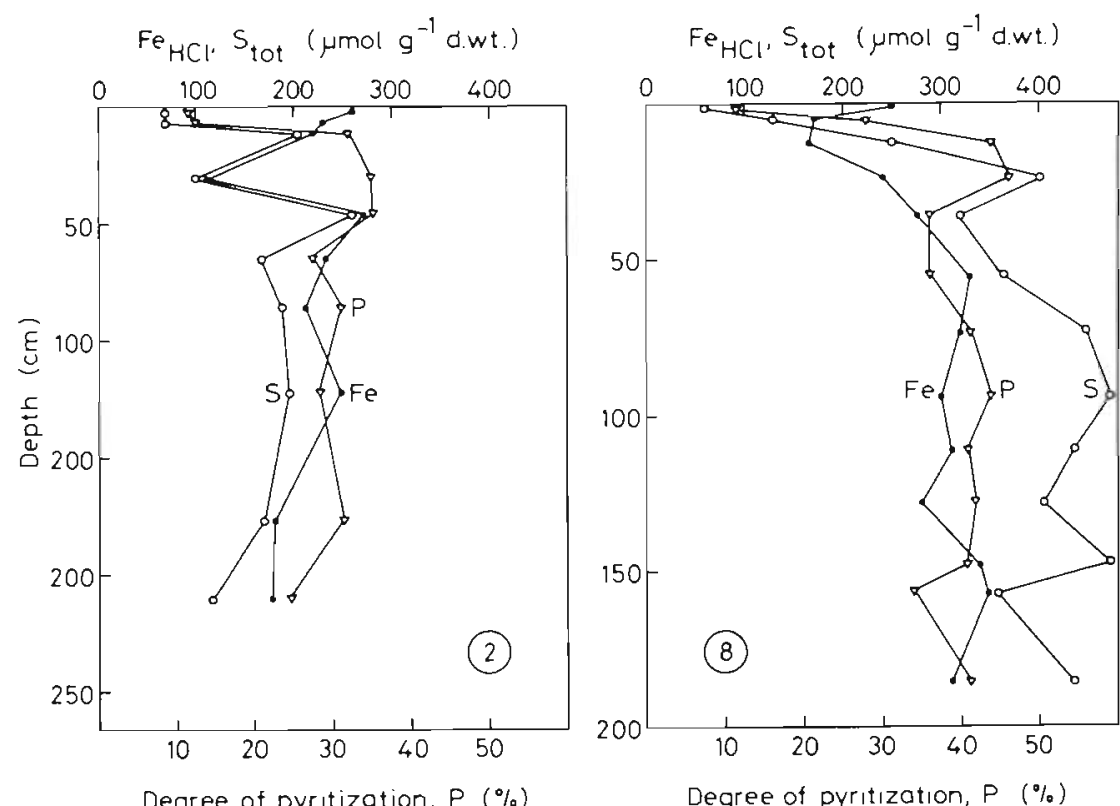

Degree of pyritizotion, P $(\%)$

$\mathrm{Fe}_{\mathrm{HCl}}, \mathrm{S}_{\mathrm{tot}}\left(\mu \mathrm{mol} \mathrm{g}^{-1} \mathrm{~d} . \mathrm{wt}\right.$ )

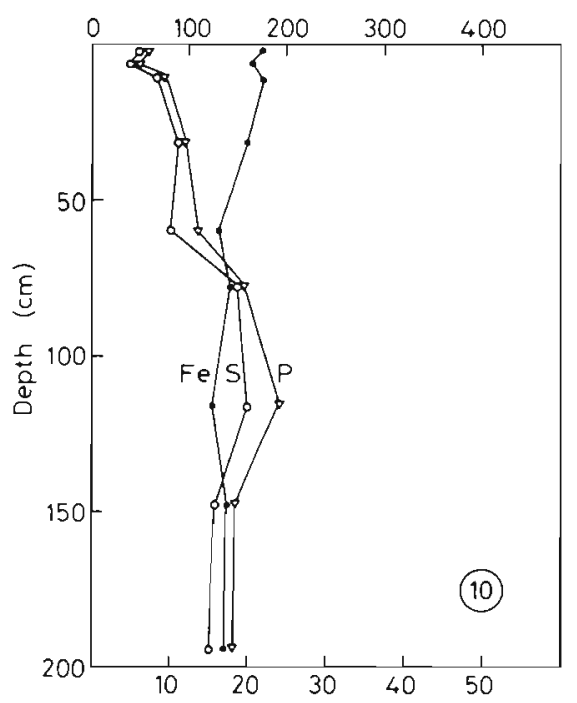

Degree of pyritization. P $(\%)$
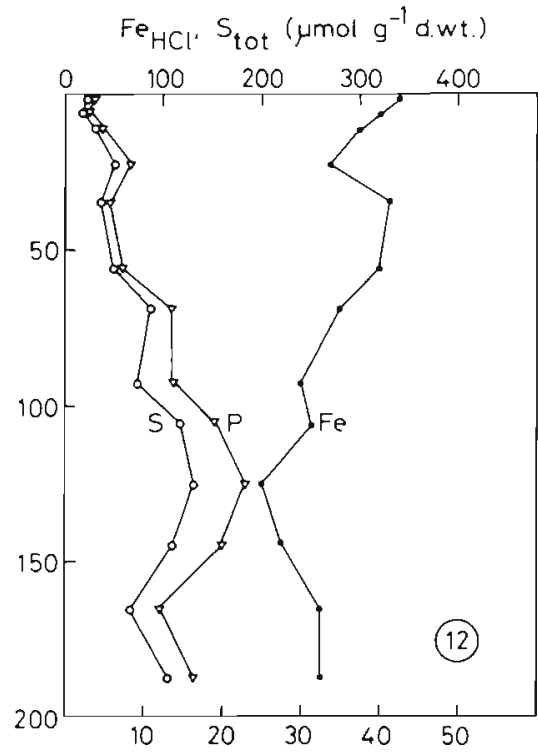

Degree of pyritization, P $(\%)$ gone repeated cycles of deposition and resuspension. As the organic matter was buried deeper at Stn 10 the $\mathrm{C}: \mathrm{N}$ ratio increased by about $50 \%$.

The C:S ratio decreased at both stations over the upper few decimetres, where the formation of pyrite mostly took place, and approached molar ratios of 8 and 14. The accumulation and burial of organic carbon and sulfur to depths below the sulfate zone is calculated for 6 stations in Table 3 . The burial ratio for the 2 elements is calculated with respect to their weight and their oxidation equivalents ( 1 mol organic $C$ is 4 equivalents while $1 \mathrm{~mol}$ pyrite $\mathrm{S}$ is 8 equivalents if oxidized completely to
$\mathrm{CO}_{2}$ and $\mathrm{SO}_{4}{ }^{2-}$ ). The weight ratios ranged from 1.8 to 7.2 . The ratios were higher at the higher sedimentation rates and were inversely related to the degree of pyritization (Table 2). At Stns 10 and 12, where $P$ was only 17 to $19 \%$, the C:S ratio was significantly higher than the mean weight ratio of 2.8 calculated for marine shelf sediments (Berner \& Raiswell 1983).

The buried organic carbon is only a fraction of the total net carbon influx. The latter was not directly measured by sediment traps but is here calculated based on measured parameters. The predominant loss of organic carbon due to oxidation to $\mathrm{CO}_{2}$ is caused by aerobic and 


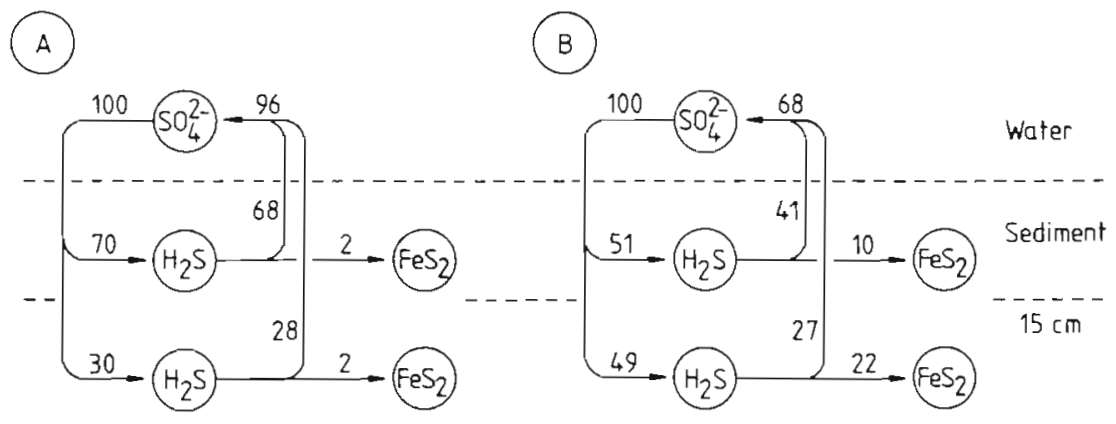

Fig. 8. Budgets of the sulfur cycle at 2 stations. Depth-integrated rates are calculated for 0 to $15 \mathrm{~cm}$ depth and for 15 to $\infty \mathrm{cm}$, where $\infty$ is the lower boundary of the sulfate zone. Rates are expressed as percent of the overall reduction in the sulfate zone. (A) Stn 2 with the relatively lowest pyrite formation and with an overall sulfate reduction $(=100 \%)$ of $4.67 \mathrm{mmol} \mathrm{m}^{-2} \mathrm{~d}^{-1}$ (B) Stn 10 with the relatively highest pyrite formation and with an overall sulfate reduction of 5.61 mmol m $\mathrm{m}^{-2} \mathrm{~d}^{-1}$ anaerobic respiration. The total oxygen uptake of the sediments includes: the direct respiration by heterotrophic fauna and microbes, the respiration by lithotrophic bacteria which oxidize sulfide, ammonia, ferrous iron, etc., and the chemical oxidation reactions. Not included is in particular that part of the sulfate respiration which leads to trapped metal sulfides in the sediment (cf. Jørgensen 1982). This part is equivalent to the burial rate of pyrite. It should be multiplied by 2 to account for the stoichiometry of sulfate reduction vs carbon oxidation. The total net influx of organic carbon should therefore be equal to the total oxygen uptake rate plus 2 times the pyrite accumulation rate plus the burial rate of organic carbon.

The calculated carbon influx for the 6 stations is shown in Table 3 . For most of the stations the influx varied only from 12.0 to $27.7 \mathrm{mmol} \mathrm{C} \mathrm{m}^{-2} \mathrm{~d}^{-1}$, but at Stn 10 it was $52 \mathrm{mmol} \mathrm{C} \mathrm{m} \mathrm{Cd}^{-1}$. The mean annual primary production of the area is 100 to $200 \mathrm{~g} \mathrm{C} \mathrm{m}^{-2}$ $\mathrm{yr}^{-1}$ or 23 to $45 \mathrm{mmol} \mathrm{C} \mathrm{m} \mathrm{C}^{-1}$. The mean carbon influx to the sediment was thus about $50 \%$ of the plankton productivity. The much higher percentage for Stn 10 was explained by the allochtonous source of much of the sedimenting organic carbon.

Also shown in Table 3 is the fraction of the carbon influx which becomes permanently buried into deeper layers of the sediment. This fraction increased with sedimentation rates from $9 \%$ at Stn 2 to $50 \%$ at Stn 10 . The burial rates of organic $\mathrm{N}$ at the same stations were 0.08 and $1.3 \mathrm{mmol} \mathrm{N} \mathrm{m}^{-2} \mathrm{~d}^{-1}$

\section{DISCUSSION}

\section{Distribution of sulfate reduction rates}

The depth-integrated rates of sulfate reduction measured in the present study, 2.38 to $7.91 \mathrm{mmol} \mathrm{m}^{-2} \mathrm{~d}^{-1}$, were in the lower to middle range of rates measured in other coastal and shelf sediments (cf. Skyring 1987). The depth distribution of sulfate reduction is generally a function of the sedimentation rate, $w$, and thus of the organic flux to the sediment surface, which again deter- mines the areal rate of sulfate reduction (Jørgensen 1982). In nearshore sediments with high $\omega$ a relatively sharp peak of sulfate reduction is found close to the sediment surface. As coastal distance and water depth increase and $\omega$ decreases, sulfate reduction is depressed to deeper sediment layers and the reduction peak broadens. Thus, the maximal reduction rates decrease more rapidly than the areal rates (Jørgensen 1983). Toth \& Lerman (1977) and Berner (1978) found accordingly that, over a wide range of sedimentation rates in marine sediments, the first-order rate constant for sulfate reduction varied in proportion to $\omega^{2}$. The sulfate flux across the sediment-water interface, and thus the depth-integrated sulfate reduction rate, was proportional to $\omega$.

These trends were exceeded in Baltic Sea-North Sea transition sediments by an opposed effect of bioturbation and mixing. Mixing depths varied in proportion to sedimentation rates which is not a general phenomenon in shelf sediments. As a result, Stns 3 and 8 with low $\omega\left(0.3\right.$ to $\left.0.5 \mathrm{~mm} \mathrm{yr}^{-1}\right)$ and shallow mixing depth (5 to $10 \mathrm{~cm}$ ) had the sharpest peaks of sulfate reduction closest to the surface, at 4 to $5 \mathrm{~cm}$ depth. Stns 9, 10, and 12 with high $\omega$ of 1.6 to $6.2 \mathrm{~mm} \mathrm{yr}^{-1}$ and deep mixing depth $(15$ to $23 \mathrm{~cm})$ had broad sulfate reduction peaks at 10 to $20 \mathrm{~cm}$ depth.

The combined effect of high sedimentation and deep mixing in the latter group of stations was to enhance the burial of relatively fresh and easily degradable organic matter deep into the sulfate reduction zone Stn 9 was the extreme example of this with the highest depth-integrated rate of sulfate reduction but the lowest rate in the upper 0 to $15 \mathrm{~cm}$ (Table 2). Another effect of the enhanced burial of organic matter was to shift sulfate reduction. to deeper sediment layers where slow molecular diffusion was the dominant transport mechanism rather than the faster advective transport, which dominates in the bioturbated zone. The slower transport caused the sulfate to become depleted at more shallow depths of $\leq 1 \mathrm{~m}$ at Stns 12 and 9 in spite of the deep mixing zone. There was thus not a simple relation between depth-integrated sulfate reduction rates and depths of sulfate depletion. These trends are apparent from the cumulative plot in Fig. 6 . 
Fig. 9. Total $\mathrm{C}, \mathrm{N}$, and $\mathrm{S}$ concentrations in the sediment at Stn 2 (top) and Stn 10 (bottom); molar ratios of total $\mathrm{C}: \mathrm{N}$ and total C:S are calculated for the same stations
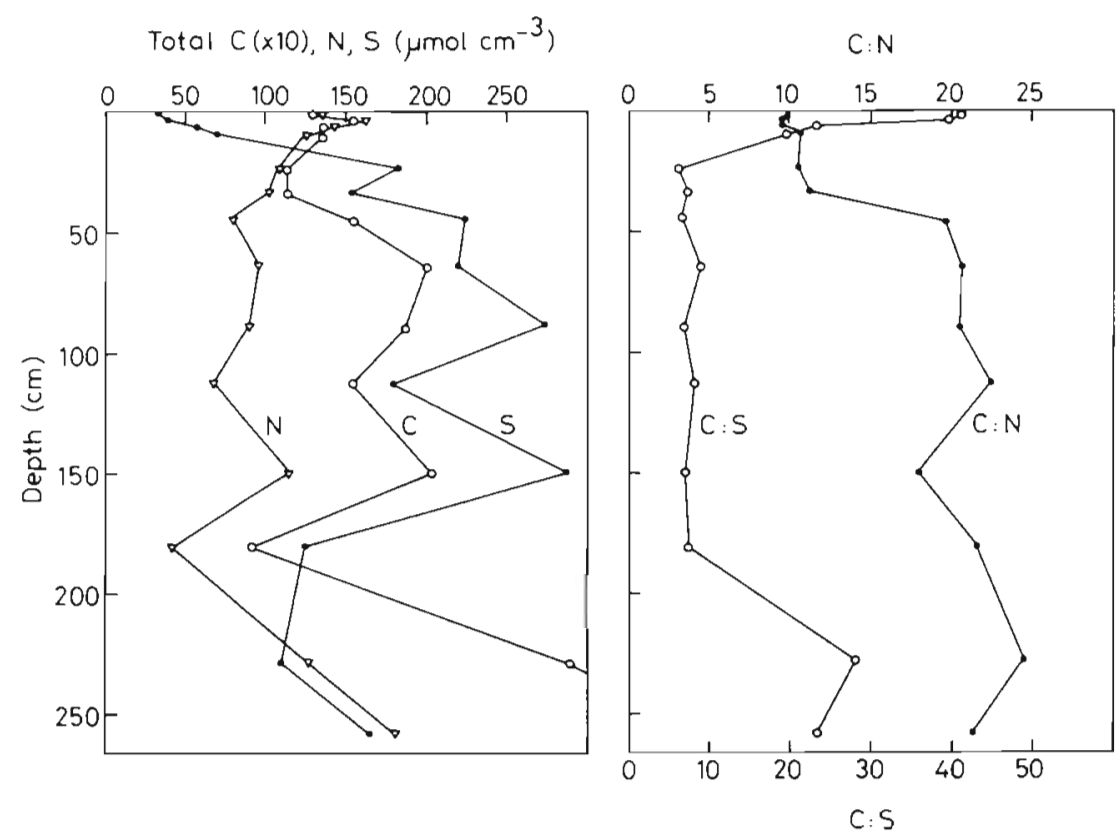

Total $C(\times 10)$, N, S $\left(\mu \mathrm{mol} \mathrm{cm}^{-3}\right)$

$C: N$

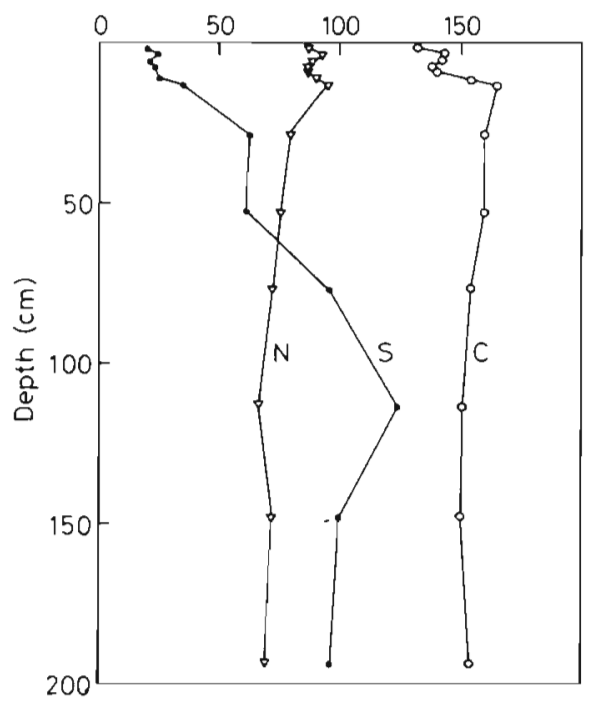

The following calculations further illustrate the role of burial rate. If we assume passive burial of deposited organic matter from the surface to $75 \mathrm{~cm}$ depth, the age after burial can be estimated from the sediment accumulation rate (compaction as calculated from vertical porosity gradients was only 10 to $15 \%$ between $15 \mathrm{~cm}$ and $2 \mathrm{~m}$ depth and is not considered). For Stns 2 and 10 the ages at $75 \mathrm{~cm}$ should be 2500 and $120 \mathrm{yr}$, respectively. The measured sulfate reduction rates at the same depth were 0.15 and $1.3 \mathrm{nmol} \mathrm{cm}^{-3} \mathrm{~d}^{-1}$, respectively. As the concentrations of organic carbon were 1.1 and $1.3 \mathrm{mmol} \mathrm{C} \mathrm{cm}^{-3}$, the theoretical turnover times of the carbon pool were about 10000 and $1400 \mathrm{yr}$. respectively. The higher $\omega$ and mixing depth thus caused more rapidly degradable organic matter to be buried to the lower part of the sulfate zone.

The semi-log plots of sulfate reduction versus depth (Figs, 2 to 5) show clearly that reduction rates do not decrease exponentially with depth and age of the organic matter. First-order reaction kinetics thus do not describe the depth and time course of organic matter mineralization adequately. Rather, the sequence of mineralization can be formally described as the net result of decay of multiple pools, each having its own first-order rate constant of decomposition (Jørgensen $1978 b)$. The rapidly degradable pools with high rate 
Table 3. Accumulation of organic carbon and of sulfur at 6 sediment stations: organic C concentration at the lower boundary of the sulfate zone ( $\infty$ ); net accumulation of organic $C$ and of pyrite $S$ at $x$ depth; ratio of $C$ and $S$ burial rates based on weights and on oxidation equivalents, respectively; total influx of organic $\mathrm{C}$ to the sediment; percent of total organic $\mathrm{C}$ influx which becomes buried below the sulfate zone

\begin{tabular}{|c|c|c|c|c|c|c|c|c|}
\hline \multirow[t]{2}{*}{$\operatorname{Stn}$} & \multicolumn{2}{|c|}{$\begin{array}{l}\text { Organic } C \\
\text { mean at } \infty\end{array}$} & \multicolumn{2}{|c|}{$\begin{array}{c}\text { Accum. rate } \\
\left(\mathrm{mmol} \mathrm{m} \mathrm{m}^{-2} \mathrm{~d}^{-1}\right)\end{array}$} & \multicolumn{2}{|c|}{$\begin{array}{c}\text { Burial ratio } \\
\text { C:S }\end{array}$} & \multirow{2}{*}{$\begin{array}{c}\text { Cinflux } \\
\left(\text { mmol } m^{-2} d^{-i}\right)\end{array}$} & \multirow{2}{*}{$\begin{array}{c}\text { C buried } \\
\text { vs } \mathrm{C}_{\text {in }} \\
(\%)\end{array}$} \\
\hline & (\% dry wt) & $\left(\mathrm{mmol} \mathrm{cm} \mathrm{cm}^{-3}\right)$ & Org. C & $\mathrm{FeS}_{2}$ & $\mathrm{~g}: \mathrm{g}$ & eq:eq & & \\
\hline 2 & 3.2 & 1.8 & 1.48 & 0.187 & 3.0 & 4.5 & 16.7 & 9 \\
\hline 6 & 1.9 & 1.1 & 1.51 & 0.152 & 3.7 & 5.7 & 12.0 & 13 \\
\hline 8 & 2.9 & 1.5 & 2.1 & 0.43 & 1.78 & 2.7 & 15.4 & 14 \\
\hline 9 & 3.4 & 2.0 & 8.8 & 0.76 & 4.3 & 6.6 & 22.3 & 39 \\
\hline 10 & 2.2 & 1.6 & 26 & 1.77 & 5.6 & 8.5 & 52.3 & 50 \\
\hline 12 & 2.1 & 1.6 & 12.7 & 0.66 & 7.2 & 11.0 & 27.7 & 46 \\
\hline
\end{tabular}

constants will dominate the overall reduction rates near the surface. In deeper layers these pools have been exhausted and more refractory pools with lower rate constants remain. Berner (1980b) used a 'multi-Gmodel', where $G$ designates organic carbon pools, each of which undergoes exponential decay, to estimate sulfate reduction in coastal sediments. Westrich \& Berner (1984) provided experimental evidence for this model by studying the time course of organic matter mineralization in laboratory microsoms.

As the present study was done before the recognition of 'rapid pyrite formation' (Howarth 1979), only reduced ${ }^{35} \mathrm{~S}$ incorporated into acid-volatile sulfides was analyzed. Later studies have shown that a significant fraction of the $\mathrm{H}_{2}{ }^{35} \mathrm{~S}$ produced can be recovered in pyrite or elemental sulfur, even after a few hours incubation (Howarth \& Teal 1979, Howarth \& Jørgensen 1984, Howes et al. 1984, King et al. 1985). In a survey of Danish coastal marine sediments this fraction was found to range form 20 to $60 \%$ (mostly 40 to $50 \%$ ) when areal sulfate reduction rates were in the range of 3 to $8 \mathrm{mmol}$ $\mathrm{m}^{-2} \mathrm{~d}^{-1}$ as found here (Thode-Andersen \& Jørgensen 1989). In offshore sediments with lower sulfate reduction rates ${ }^{35} \mathrm{~S}$ in AVS comprises an even lower fraction of total $\mathrm{H}_{2}{ }^{35} \mathrm{~S}$ produced (Christensen 1989). The present sulfate reduction rates are consequently underestimated by roughly this magnitude. As the actual underestimation is not known. we have chosen not to attempt any correction of the present data.

\section{Methane}

In several of the depth curves of sulfate reduction rate and bacterial density there was a conspicuous increase at the transition between the sulfate and methane zones. It has been shown both by direct radiotracer studies and by diffusion-diagenesis modeling that anaerobic methane oxidation and elevated sulfate reduction rates coincide in this transition zone (e.g. Reeburgh 1980,
Iversen \& Jørgensen 1985). It was not planned in the present research, however, to study such an effect and the sampling density was therefore too low to demonstrate a distinct activity maximum at the sulfatemethane transition. A peak of activity at the transition will act as a sulfate sink at the lower boundary of the sulfate zone. This tends to create straighter sulfate profiles with stronger curvature at the bottom in accordance with many observed gradients (cf. Berner 1980a).

Methane concentrations exceeded atmospheric pressure below the sulfate zone at the Skagerrak and northern Kattegat stations. Seismic studies in these areas have demonstrated the occurrence of gas bubbles at several meters below the sediment surface (Fält 1982). The in situ partial pressure of methane at that depth thus exceeds the ambient hydrostatic pressure of 6 to $20 \mathrm{~atm}$. The source of methane is probably mostly bacterial production in the unconsolidated sediments below the sulfate zone. Deeper methane sources of thermogenic origin which penetrate up through the sediment-water interface have, however, also been found in recent years. This phenomenon is seen in limited areas of northern Kattegat, where continuous ebullition takes place, or in more scattered areas of southern Skagerrak, where visible 'pockmarks' occur as the result of methane eruptions.

\section{Pyritization}

The porewater concentration of $\mathrm{H}_{2} \mathrm{~S}$ was found to build up below the mixing zone and to reach maxima of 0.6 to $>2 \mathrm{mM}$ at the sulfate-methane interface. The $\mathrm{H}_{2} \mathrm{~S}$ reacts with the large iron pools in the sediment to form FeS as the immediate product. At stations with low (1) (Stns 2 and 8), the FeS formation was evident from sharp black bands in the upper 5 to $15 \mathrm{~cm}$ of sediment (Figs. 2 and 3). In sediment buried into the grey pyrite zone below $20 \mathrm{~cm}$, the FeS had been transformed into $\mathrm{FeS}_{2}$. Pyritization was largely concluded within the upper 0 to 
$15 \mathrm{~cm}$ at Stns 2 and 8 (Fig. 7). The high-w sediments, in contrast, had high FeS concentration throughout the sulfate zone (Figs. 4 and 5). Pyritization increased through most of the sulfate zone but involved only about $20 \%$ of the extractable iron pool (Fig. 7).

The relatively low efficiencies of pyritization, 17 to $42 \%$, are typical of marine sediments (Berner 1970). It is not clear what regulates the conversion of FeS into pyrite or the trapping of detrital iron by sulfide. Since the iron pool does not react with $\mathrm{mM}$ concentrations of $\mathrm{H}_{2} \mathrm{~S}$ it is clearly not very reactive although it is readily extractable with strong acid. The iron may be bound in silicate minerals and thereby be protected against bacterial or chemical reduction (Canfield 1989b). As the conversion of FeS to $\mathrm{FeS}_{2}$ involves reaction with elemental sulfur, possibly in the form of polysulfides, the reaction may be limited by a low availibility of $S^{\circ}$ under highly reducing conditions prevailing in the high-w sediments. As a consequence of the low iron reactivity, $\mathrm{H}_{2} \mathrm{~S}$ is allowed to build up in the porewater and 68 to $96 \%$ of the $\mathrm{H}_{2} \mathrm{~S}$ is lost from the sediment (Fig. 8).

\section{Burial of $\mathrm{C}, \mathrm{N}, \mathrm{S}$, and $\mathrm{Fe}$}

Due to the net accumulation of sediments, the main elements of the organic matter are buried deep below the surface and may ultimately be incorporated into sedimentary rock. The burial of reduced carbon, nitrogen, sulfur, and iron is of general importance both for the cycling of elements and for the redox balance on the surface of Earth. Thus, the level of atmospheric oxygen is balanced over geological periods by the living and buried biomass. The highly reducing shelf sediments cover only $10 \%$ of the ocean area but bury about $90 \%$ of the organic carbon (Berner 1982).

The burial efficiency, $E_{1}$ defined as the fraction of the total deposited organic matter which becomes buried into deep sediment layers, was discussed recently by Henrichs \& Reeburgh (1987). From compiled literature data they found an empirical relation between $E$ and net sedimentation rate, $\omega\left(\mathrm{cm} \mathrm{yr}^{-1}\right): E=\omega^{0.4} / 2.1$.

Although there is a large scatter in this relationship, the correlation is good when estimated over many decades of $\omega$. When the relation is applied to the range of net sedimentation rates measured here, 0.3 to $6.2 \mathrm{~mm} \mathrm{yr}^{-1}$, we find $E$ values for organic carbon of 12 to $39 \%$, with extreme values at Stns 2 and 10 . This is close to the actual burial efficiencies of 9 to $50 \%$ which were calculated for the same stations (Table 3 ).

The burial ratio of $\mathrm{C}: \mathrm{S}$, calculated as oxidation equivalents, varied from 2.7 to 11.0 with extreme low and high values at Stns 8 and 12 , respectively (Table 3). A ratio of $2.7 \mathrm{eq}$ :eq means that reduced sulfur accounts for $(1 /[1+2.7]) 100=27 \%$ of the reducing power buried. At a ratio of 11.0 , sulfur accounts for only $8 \%$. The burial of sulfur is thus a minor, but still significant fraction of the reducing power in the sediments.

Iron plays a minor role in this respect in spite of the large iron deposition. Acid-soluble iron accounted for only about $3.5 \%$ of the total reducing power at both Stns 2 and 10. There was Iittle variation in this percentage between stations. This is due to a relatively constant ratio of $\mathrm{C}$ and $\mathrm{Fe}$ deposition. The large variation in C:S ratio of the sediments (Table 3 ) is thus due to variations in the degree of pyritization rather than to variations in iron content.

The nitrogen burial can be calculated from carbon burial rates and from C: $N$ molar ratios at depth in the sediment (Fig. 9). At Stns 2 and 10 the $C: N$ ratio was 22 at $2 \mathrm{~m}$ below the sediment surface and $\mathrm{N}$ burial was thus 0.07 and $1.2 \mathrm{mmol} \mathrm{m}^{-2} \mathrm{~d}^{-1}$, respectively. This can be compared to the mean nitrogen requirement for planktonic primary production in the overlying water masses. The mean annual production ranged from 100 to $200 \mathrm{~g} \mathrm{C} \mathrm{m}^{-2}$ with highest values in the Belt Sea. With a mean $C: N$ ratio of 7 in freshly produced plankton, the $\mathrm{N}$ requirement would be about $6 \mathrm{mmol} \mathrm{N} \mathrm{m}^{-2} \mathrm{~d}^{-1}$ at Stn 2 and 3 to $4 \mathrm{mmol} \mathrm{N} \mathrm{m}{ }^{-2} \mathrm{~d}^{-1}$ at Stn 10. The comparison shows that net burial of $N$ was equivalent to only $1 \%$ of the plankton requirement at Stn 2. Much of this production is, however, based on nutrients regenerated in the water column. In the northern Kattegat, net burial (Stn 10) removed a large pool of combined nitrogen from circulation.

Acknowledgements. We thank Preben G. Sørensen and Kirsten Maagaard for technical assistance and Niels Peter Revsbech for performing alkalinity titrations. Total $\mathrm{C}$ and $\mathrm{N}$ analyses were done by Preben Hansen, University of Copenhagen. Dating of sediments by ${ }^{210} \mathrm{~Pb}$ and determination of sedimentation rates were done by Poul Pfeiffer Madsen, Danish Isotope Centre. A Kullenberg piston corer was kindly provided by the Danish Geological Survey with the help of Henner Bahnson. The study was supported by the Danish Natural Science Research Council (grant nos. 511-10529 and 511-15481).

\section{LITERATURE CITED}

American Public Health Association (1971). Standard methods for the examination of water and wastewater, 13th edn. Washington, D.C.

Berner, R. A. (1970). Sedimentary pyrite formation. Am. J. Sci. 268: 1-23

Berner, R. A. (1978). Sulfate reduction and the rate of deposition of marine sediments. Earth Planet. Sci. Lett. 37: 492-498

Berner, R. A. (1980a). Early diagenesis: a theoretical approach. Princeton University Press, Princeton, N.J

Berner, R. A. (1980b). A rate model for organic matter decomposition during bacterial sulfate reduction in marine sediments. In: Biogeochemie de la matière organique a l'inter face eau sediment marin. Colloques int. Cent. Natn. Rech. scient. 293: $35-44$ 
Berner, R. A. (1982). Burial of organic carbon and pyrite sulfur in the modern ocean: its geochemical and environmental significance. Am. J. Sci. 282: 451-473

Berner, R. A., Raiswell, R. (1983). Burial of organic carbon and pyrite sulfur in sediments over Phanerozoic time: a new theory. Geochim. Cosmochim. Acta 47: 855-862

Blackburn, T. H., Henriksen, K. (1983). Nitrogen cycling in different types of sediments from Danish waters. Limnol. Oceanogr. 28: 477-493

Canfield, D. E. (1989a). Sultate reduction and oxic respiration in marine sediments: implications for organic carbon preservation in euxinic environments. Deep Sea Res. 36: $121-138$

Canfield, D. E. (1989b). Reactive iron in marine sediments. Geochim. Cosmochim. Acta 53: 619-632

Chan, K. M., Riley, J. P. (1970). The automated determination of phosphate in sea water. Deep Sea Res. 13: 417-421

Christensen, J. P. (1989). Sulphate reduction and carbon oxidation rates in continental shelf sediments, an examination of offshelf carbon transport. Cont. Shelf Res. 9: 223-246

Cline, J. D. (1969). Spectrophotometric determination of hydrogen sulfide in natural waters. Limnol. Oceanogr. 14 $454-458$

Dale, N. G. (1974). Bacteria in intertidal sediments. Factors related to their distribution. Limnol. Oceanogr. 19 $509-518$

Fält, L.-M. (1982). Late quaternary sea-floor deposits off the Swedish west coast. Dept Geology, University of Gothenburg, Publ. A 37, p. 1-259

Henrichs, S. M., Reeburgh, W. S. (1987). Anaerobic mineralization of marine sediment organic matter: rates and the role of anaerobic processes in the oceanic carbon economy. Geomicrobiol. J. 5: 191-237

Hobbie, J. E., Daley, R. J., Jasper, S. (1977). Use of nucleopore filters for counting bacteria by fluorescence microscopy. Appl. environ. Microbiol. 33: 940-954

Howarth, R. W (1979). Pyrite: its rapid formation in a salt marsh and its importance in ecosystem metabolism. Science 203: 49-51

Howarth, R. W., Jorgensen, B. B. (1984). Formation of ${ }^{35} \mathrm{~S}$ labelled elemental sulfur and pyrite in coastal marine sediments (Limfjorden and Kysing Fjord, Denmark) during short-term ${ }^{35} \mathrm{SO}_{4}{ }^{2-}$ reduction measurements. Geochim. Cosmochim. Acta 48: 1807-1818

Howarth, R. W., Teal, J. M. (1979). Sulfate reduction in a New England salt marsh. Limnol. Oceanogr. 24: 999-1013

Howes, B. L., Dacey, J. W., King, G. M. (1984). Carbon flow through oxygen and sulfate reduction pathways in salt marsh sediments. Limnol. Oceanogr. 29: 1037-1051

Iversen, N., Jørgensen, B. B. (1985). Anaerobic methane oxidation rates at the sulfate-methane transition in marine sediments from Kattegat and Skagerrak (Denmark). Limnol. Oceanogr. 30: 944-955

Jorgensen, B. B. (1977). The sulfur cycle of a coastal marine sediment (Limfjorden, Denmark). Limnol. Oceanogr. 22 $814-832$

Jørgensen, B. B. (1978a). A comparison of methods for the quantification of bacterial sulfate reduction in coastal marine sediments. 1. Measurements with radiotracer techniques. Geomicrobiol. J. 1: 11-27

Jørgensen, B. B. (1978b). A comparison of methods for the quantification of bacterial sulfate reduction in coastal

This article was submitted to the editor marine sediments. 2. Calculation from mathematical models. Geomicrobiol. J. 1: 29-51

Jørgensen, B. B. (1982). Mineralization of organic matter in the sea bed - the role of sulphate reduction. Nature, Lond. 296: 643-645

Jørgensen. B. B. (1983). The microbial sulphur cycle. In: Krumbein, W. E. (ed): Microbial geochemistry, Blackwell, London, p. 91-124

Jergensen, B. B. (1989). Sulfate reduction in marine sediments from the Baltic Sea-North Sea transition. Ophelia 31: 1-15

Jørgensen, B. B., Revsbech, N. P. (1989). Oxygen uptake, bacterial distribution, and carbon-nitrogen-sulfur cycling in sediments from the Baltic Sea-North Sea transition. Ophelia 31 in press

Kanneworff, E., Nicolaisen, W. (1973). The 'Haps', a frame supported bottom corer. Ophelia 10: 119-128

King, G. M., Howes, B. L., Dacey, J. W. H. (1985). Short-term endproducts of sulfate reduction in a salt marsh: formation of acid volatile sulfides, elemental sulfur, and pyrite. Geochim. Cosmochim. Acta 49: 1561-1566

Larsen, B., Madsen, P. P. (1986). Accumulation of mud sediments and trace metals in the Kattegat and the Belt Sea. Manne Pollution Laboratory, Charlottenlund, Denmark, p. $1-68$

Madsen, P. P., Sørensen, J. (1979). Validation of the lead-210 dating method. J. radioanalyt. Chem. 54: 39-48

Redfield, A. C. (1958). The biological control of chemical factors in the environment. Am. Sci. 46: 206-226

Redfield, A. C., Ketchum, B. H., Richards, F. A. (1963). The influence of organisms on the composition of seawater. In: Hill, M. N. (ed.) The sea, Vol. 2. Interscience Press, New York, p. 26-77

Reeburgh, W. S. (1967). An improved interstitial water sampler Limnol. Oceanogr. 12: 163-165

Reeburgh, W. S. (1980). Anaerobic methane oxidation: rate depth distributions in Skan Bay sediments. Earth Planet. Sci. Lett. 47: 345-352

Rickard, D. T. (1975). Kinetics and mechanisms of pyrite formation at low temperatures. Am. J. Sci. 274: 941-952

Rublee, P. A., Dornseif, B. E. (1978). Direct counts of bacteria in the sediments of a North Carolina salt marsh. Estuaries 1 188-191

Skyring, G. W. (1987). Sulfate reduction in coastal ecosystems Geomicrobiol. J. 5: 295-374

Solòzano, L. (1969). Determination of ammonia in natural waters by the phenolhypochlorite method. Limnol. Oceanogr 14: 799-801

Sorensen, J., Jorgensen, B. B. (1987). Early diagenesis in sediments from Danish coastal waters: microbial activity and $\mathrm{Mn}-\mathrm{Fe}-\mathrm{S}$ geochemistry. Geochim. Cosmochim. Acta 51: $1583-1590$

Thode-Andersen, S., Jorgensen, B. B. (1989). Sulfate reduction and the formation of ${ }^{35} \mathrm{~S}$-labelled $\mathrm{FeS}, \mathrm{FeS}_{2}$, and $\mathrm{S}^{\circ}$ in coastal marine sediments. Limnol. Oceanogr. 34: 793-806

Toth, D. J., Lerman, A. (1977). Organic matter reactivity and sedimentation rates in the ocean. Am. J. Sci. 277:465-485

Westrich, J. T., Berner, R. A. (1984). The role of sedimentary organic matter in bacterial sulfate reduction. the $\mathrm{G}$ model tested. Limnol. Oceanogr. 29: 236-249

Winn, K. (1974). Present and postglacial sedimentation in the Great Belt channel (Western Baltic). Meyniana 26: 63-104

Manuscript first received: May 31, 1989

Revised version accepted: October 2, 1989 